BENM 2021

International Scientific and Practical Conference "Biotechnology, Ecology, Nature Management"

\title{
MORPHOLOGICAL FEATURES AND SECRETORY ACTIVITY OF INGUINAL GLAND OF MARTES ZIBELLINA L.
}

\author{
Zinaida S. Ruchkina (a)*, Alexandra Yu. Ryzhkova (b), Tatyana I. Horeva (c) \\ *Corresponding author
}

(a) Institute of Biotechnologies and Fisheries, K.G. Razumovsky Moscow State University of Technologies and Management (the First Cossack University), Moscow, Russia, zinaidaru17@yandex.ru

(b) Institute of Biotechnologies and Fisheries, K.G. Razumovsky Moscow State University of Technologies and Management (the First Cossack University), Moscow, Russia, blackzzzmamba@yandex.ru

(c) K.G. Razumovsky Moscow State University of Technologies and Management (the First Cossack University), Moscow, Russia, t.i.horeva@mgutm.ru

\begin{abstract}
Sable Martes zibellina L.- the valuable subject of fur farming and hunting, nevertheless, the significance of such specific skin gland as the inguinal gland still hasn't been fully studied throughout sable's life cycle. The winter season is generally recognized as "the period of rest" for sables. In the article it's demonstrated how important the inguinal gland is in the reproduction of this bright representative of the family Mustelidae and what kind of secretory activity of that gland occurs during the season of the complete sexual quiescence. It is during the winter season that histological studies of the female and male inguinal glands of the farm population of sables were carried out. The article deals with the analysis of the sequential change of that gland's functions, based on the age variability, sexual one and seasonal one. The results of lineal measurements and histological features of this specific glandular organ were analyzed in comparison with the data that were obtained earlier by other authors, and considerable material was taken for further research of inguinal glands.
\end{abstract}

2672-8575 (C) 2022 Published by European Publisher.

Keywords: Histology, inguinal gland, Martes zibellina L., morphology, sable, specific skin gland 


\section{Introduction}

Martes zibellina L.- the one of the most significant subjects of fur farming and hunting. Sable fur is appreciated both in Russia and abroad due to some unique features as the beauty, the distinctive heat saving, the silkiness and the wear-resistance. All of the above facts prove the special relevance of researches in the field of biology of this bright representative of the family Mustelidae.

\section{Problem Statement}

The role and features of the functioning of the sable inguinal gland still haven't been fully studied, especially in the winter season.

\section{Research Questions}

The preceding reproductive system's investigations of Martes zibellina L. have already provided some evidence for the participation of inguinal gland in this system throughout the entire life span of the species. The influence of the inguinal gland's secret on the frequent ailment of sables that is called the intertrigo or "wet belly" (as the term "urinary incontinence", but in other meaning) is of great interest for many specialists of the sable breeding. "Wet belly" causes the defects of pelt and fur, that's why this seasonal ailment presents the economic and farm value.



Figure 1. The schematic location of the inguinal gland on the sable body: on the left - the reduced carcass size of a sable, on the right - the increased fragment from the side of core (the inner skin), the shrunken thickenings - the picture of the inguinal gland in a state of rest (Artist: A. Ryzhkova) 
Regarding to the location of the inguinal gland, this compartment of secretion presents in the form of two flattened slightly yellow thickenings on the internal side of the dermis, another words it has the explicit lateral profile of the pair convex lobules. The inguinal gland has a position as to urogenital region in the following order. That organ is distinguished on the caudal part of a male body near an entrance of the urogenital region and the two milk nipples of a female body on the both sides of the lateral gland. There is the view of the inguinal gland's location of Martes zibellina L. on instance of male schematically on the figure 1. This gland organ possesses the characteristic and unique structure thanks to the histological image and the external examination of sable (the exceptional composition of hair and the mentioned skin thickenings). On the figure 2 the inguinal glands of female and male under that study are demonstrated.

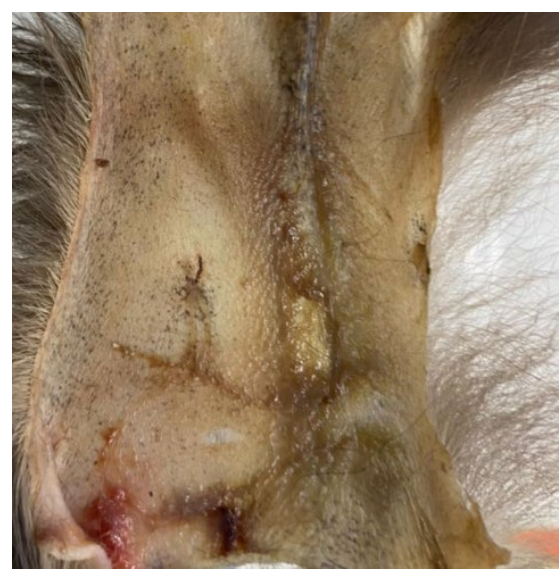

(a)

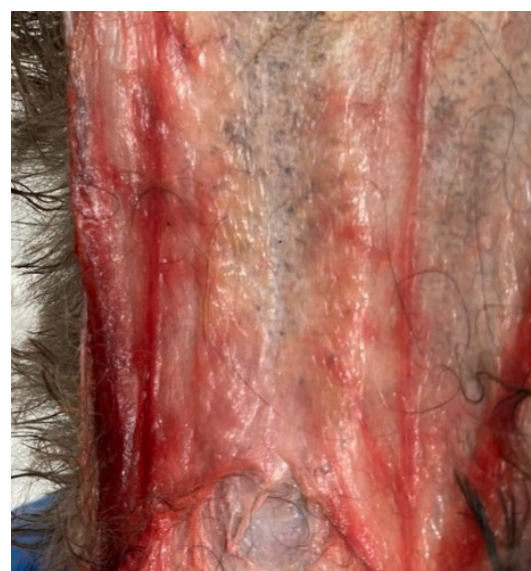

(b)

Figure 2. (a) \& (b) The photographs of the inguinal glands on the back of the pelts: the left photo (a) the female pelt, the right photo (b) - the male pelt

The marking of the inguinal gland's secret is the widespread phenomenon of sables. During the sable rutting season, its gland excretes the secret as the oily brownish fluid with the specific odor in the most quantity (Manteyfel, 1934; Starkov, 1947). That's why even some researchers name it "odorous gland" (Monakhov \& Leontyev, 1968; Rozhnov, 2011).

Only martens of the genus Martes and wolverines of the genus Gulo have the same ones with the sable inguinal gland from the whole family Mustelidae (Rozhnov, 2011). On this way some similarity to the "odorous gland" is possessed by American badger of the genus Taxidea (Pocock, 1925).

The inguinal gland is predominantly characterized by the age variability, the sex one and seasonal one.

\subsection{Age variability of the inguinal gland}

There is the inguinal gland's measurements of length (millimetres) and mass (milligrams) as to the data of various researchers in the Table 1.

The inguinal gland of sable cub wasn't well noticeable in the first day. The same situation was obtained in the seventh day. When sables reached the age of 37th day, it would have the inguinal glands 
that were been possible to touch on bellies of 2 out of 75 cubs. At the age of the 42-45th days all male sables have the well-visible inguinal glands (Chekalova et al., 1992).

The 46th day was the beginning framework of the inguinal gland's secretion in common. The secret was performed the sticky brownish mass with the specific odor on sable hair (Chekalova et al., 1992).

After the fourth month of the inguinal gland's development, the growth obviously stopped, and it began to decrease in size (Batalov \& Klyatis, 1982).

Table 1. Some relatively facts about the age variability of sable inguinal gland

\begin{tabular}{|c|c|c|c|c|c|}
\hline \multirow{2}{*}{$\begin{array}{c}\text { Age } \\
\text { Days } \\
\text { (cubs) }\end{array}$} & \multicolumn{2}{|c|}{ Female $q$} & \multicolumn{2}{|c|}{ Male ${ }_{0}^{\lambda}$} & \multirow[b]{2}{*}{ Data's authors } \\
\hline & $\begin{array}{c}\text { Length, } \\
\text { millimetres }\end{array}$ & $\begin{array}{c}\text { Mass, } \\
\text { milligrams }\end{array}$ & $\begin{array}{c}\text { Length, } \\
\text { millimetres }\end{array}$ & $\begin{array}{c}\text { Mass, } \\
\text { milligrams }\end{array}$ & \\
\hline $1 \mathrm{st}$ & - & - & - & - & Batalov \& Klyatis (1982) \\
\hline 7 th & - & - & - & - & Chekalova et al. (1992) \\
\hline 30 th & 11 & 60 & 14 & 250 & Batalov \& Klyatis (1982) \\
\hline 37 th & \multicolumn{4}{|c|}{ Inguinal glands of some cubs are found. } & Chekalova et al. (1992) \\
\hline 42 nd-45th & $*$ & $*$ & It's well grope & n male bellies. & Chekalova et al. (1992) \\
\hline 46th & \multicolumn{4}{|c|}{ In common the beginning of the inguinal gland secretion } & Chekalova et al. (1992) \\
\hline 60th & $*$ & 700 & $*$ & 700 & Batalov \& Klyatis (1982) \\
\hline 74th & $*$ & 520 & $*$ & 520 & Batalov \& Klyatis (1982) \\
\hline 97 th & $*$ & 1400 & $*$ & 1400 & Batalov \& Klyatis (1982) \\
\hline 105 th & $*$ & 1800 & $*$ & 1800 & Batalov \& Klyatis (1982) \\
\hline 120th & $*$ & 4150 & $*$ & 4150 & Batalov \& Klyatis (1982) \\
\hline $\begin{array}{l}183 \text { rd- } \\
213 \text { rd }\end{array}$ & 27 & 280 & 28 & 357 & Batalov \& Klyatis (1982) \\
\hline \multicolumn{6}{|l|}{$\begin{array}{l}\text { Month } \\
\text { (adults) }\end{array}$} \\
\hline January & $*$ & $*$ & \multicolumn{2}{|c|}{ The signs of secret's marking } & Batalov \& Klyatis (1982) \\
\hline \multirow{2}{*}{ March } & 36 & $*$ & $*$ & $*$ & Batalov \& Klyatis (1982) \\
\hline & $*$ & $*$ & \multicolumn{2}{|c|}{ It's barely groped. } & Ruchkina (2005) \\
\hline \multirow{2}{*}{ May } & $*$ & $*$ & $38-58$ & $*$ & \multirow{2}{*}{ Batalov \& Klyatis (1982) } \\
\hline & $*$ & $*$ & The excre & of secret & \\
\hline June & $*$ & $*$ & $15-45$ & $*$ & Ruchkina (2005) \\
\hline \multirow{4}{*}{ July } & \multicolumn{4}{|c|}{ The secretion of the oily fluid } & Petryayev (1941) \\
\hline & $32-36,5$ & $*$ & $35-57$ & $*$ & $\begin{array}{c}\text { Monakhov \& Leontyev } \\
\text { (1968) }\end{array}$ \\
\hline & 35,4 & $*$ & 45,5 & $*$ & Batalov \& Klyatis (1982) \\
\hline & $*$ & $*$ & $20-45$ & $*$ & Ruchkina (2005) \\
\hline August & $*$ & $*$ & \multicolumn{2}{|c|}{ It's barely groped. } & Ruchkina (2005) \\
\hline October & 31,5 & $*$ & $32,5-44,5$ & $*$ & $\begin{array}{c}\text { Monakhov \& Leontyev } \\
\text { (1968) }\end{array}$ \\
\hline
\end{tabular}

* There is no evidence as to this value.

Regarding to the difference in sizes of mature and young sable, the average statistics demonstrate the most values of adults (after the age of 2 years old) and the least values of young sable at the age of 1 
and 2 years old (before 16-18 months) (Batalov \& Klyatis, 1982). This phenomenon can be explained the slow process of the sable sex development (Ilina, 1963).

Some scientific authors note the significant individual variability of inguinal gland's sizes (Batalov \& Klyatis, 1982; Chekalova et al.,1992). For instance, sometimes the exceptional young individuals could possess the inguinal glands, which sizes exceed the adults, although the mentioned statistics are presented the reverse values. A similar thing occurs by the comparison of the size of the females' glands and males' ones.

\subsection{Sex variability of the inguinal gland}

The correlation of changes in the size of the inguinal glands is strongly pronounced in males' sables. This fully determines the phenomenon of sexual dimorphism among sables, in spite of the fact that the inguinal glands of both sexes increase over the years (Batalov \& Klyatis, 1982; Monakhov \& Leontyev, 1968).

Regarding to the seasonal variability in the correlation between the size of the inguinal glands and the sexual organs, it's worth noting the sexual nature of the function of the gland on the example of such a phenomenon in males as the "false rutting" (from February to May) (Monakhov \& Leontyev, 1968).

\subsection{Seasonal variability of the inguinal gland}

Seasonal variability occurs with changes in a size and a secretory variation of the inguinal glands. Table 01 shows the seasonal variability of the inguinal glands of adults throughout the year.

In the spring, the short hollow ways that appears with aid of the crawling on the belly could be seen on the tracks of sables. They also rub against objects that stand out from under the snow, such as twigs, stumps, etc. Especially often there are the same traces in the second half of winter, but there is a chance to see such places on the autumn tracks of sables (Raevskiy, 1947).

During the rut, the inguinal glands of the females and males, that especially strongly developed at this time, secrete a special oily liquid of a brownish-greenish color (Petryaev, 1941). At the end of the rut, the size of the inguinal glands decreases.

As for the intertrigo ("wet belly") of sable cubs, this ailment is characterized by the partial depigmentation of the hair on the abdomen of the pelts and frequent defects of its, but in the worst case (if the treatment is neglected) the "wet belly" causes to the mild swelling, the hyperemia of the skin, the raised temperature of affected individuals and the purulent exudate on the vulnerable area of the skin. These signs begin to appear in the first half of June, when young are separated from mothers, and this disease could appear up to the slaughter of fur cubs sometimes (Asmus, 1961; Chekalova et al., 1992). It's probably that the inguinal gland takes part in that process as the producer of the oily secret that causes the "wet belly" of sable cubs.

\subsection{The interrelationship between the inguinal gland and other organs}

There is a parallel of an inguinal gland's growth with the growth of the ovaria, the thyroid gland and the adrenal cortex throughout the first year of sable life. At 4.5 months, the ovaria of sables reach the 
mass characteristic of an adult (after it is suspended as the inguinal gland). Therefore, it can be relied on a certain dependence between the inguinal gland and the hormonal function of the ovaria (Batalov \& Klyatis, 1982).

A number of experiments and observations on the proportion of the size and weight of the inguinal gland confirmed the seasonal, age-related and sexual variability in the inguinal gland's size and functioning, and also its' direct correlation with the generative organs of Martes zibellina L. (Batalov \& Klyatis, 1982; Chekalova et al., 1992; Ruchkina, 2005). A strong expression of seasonal variations in the weight, volume and length of the gland doesn't exclude alternate changes in the function of the inguinal gland during the year. This is reflected in the marking behavior and the intraspecific relations of sables, in the preparation of the sexual sphere of the body for the rutting period and in such ailment as "wet belly" (Asmus, 1961; Chekalova et al., 1992; Slugin, 2004; Tarasov, 1960).

\subsection{The histological examination of the inguinal gland}

The great biological interest concludes the secretory glandular organs of mammals as adaptations to the conditions of existence. The inguinal gland is a specific glandular organ of a distinctive structure with the pronounced seasonal variability (Batalov \& Klyatis, 1982).

There are the skin glandular organs of Martes zibellina $L$. as the complex organs, which is composed of modified sebaceous and sweat glands (or skin appendages) (Matveev, 1942; Sokolov, 1973).

It's assumed that the secret of the inguinal gland excretes through the ducts that opens in the hair follicle under its lobules (the basis of the secret is the sebum of the sebaceous glands), which are significantly different from the nearby areas of the hair (Monakhov \& Leontyev, 1968). The mechanism of secretion of the inguinal gland is based on an irritation of hair tufts of the lever type (Tamar, 1976).

The dependence of the sebaceous glands on the stimulation or rest of the endocrine system can be constructed, where the generative glands, the adrenal cortex and the pituitary gland take a special part. The stimulation of the activity of the sebaceous glands is due to the formation of androgens (the maximum development of the inguinal glands in males is observed during the rut), while the hormones of the corpus luteum of gestation act in the opposite direction and inhibit their development (Kalantaevskaya, 1972). This can serve as the most logical explanation for the predominant development of males' inguinal glands and the phenomenon of sexual dimorphism through the studied glands in representatives of Martes zibellina L.

\section{Purpose of the Study}

The goal of the present research concludes in the study and description of the morphologic and histologic features of the sable inguinal glands of both sexes in winter season.

\section{Research Methods}

The present researches were performed with the aid of the material of inguinal glands, which were possessed by the deceased mature sables of farm population that perished in winter this year, exactly the 20th of December (the female specimen) and the 18th of January (the male specimen). Measurements of 
inguinal glands were made with a ruler. Then these organs were dissected and were fixed with $4 \%$ concentration's neutral formalin, were dehydrated in several graduated alcohols and were filled with the paraffin. The histological examinations were carried out with the using of a light microscope on the crosssections of $4 \mathrm{mkm}\left(1 \mu \mathrm{m}=10^{-6} \mathrm{~m}\right)$ thick, which previously were processed haematoxylin and eosin stain (H\&E). The optical magnifications of the microphotographs are $4 * 0,25$ (the male specimen) and $10 * 0,25$ (the female specimen).

\section{Findings}

\subsection{Morphological description of the researched inguinal glands}

The season under this study is generally recognized "the period of rest" of sables, because it's characterized the complete sexual quiescence and the decreased secretory activity of the inguinal gland.

The data concerning the inguinal glands' morphology of sable female (that deceased in December) and sable male (that deceased in January) were obtained, and was made the histological study of these organs. The measurements of inguinal glands are treated in the table 2 .

Table 2. The morphological values and data of inguinal glands under that study

\begin{tabular}{ccc}
\hline Values & Female $q$ & Male ${ }^{\lambda}$ \\
\hline Length, millimetres & 30 & 38 (the left lobule), \\
Thickness or width, millimetres & 10 & 36 (the right lobule) \\
Death data & $12 / 20 / 2020$ & 20 \\
\hline
\end{tabular}

The length and thickness or width of the male's inguinal gland was the more size than the female's gland. That's evidence of the sexual dimorphism.

A research of the hair -coat covering indicated that in a winter period the inguinal gland's hair was indistinguishable from the rest of the hair on a sable belly.

At the end of the December the measured length of the female's inguinal gland revealed $30 \mathrm{~mm}$ that the less dimension as compared with preceding researchers' data in the March (less than $36 \mathrm{~mm}$ ), and the equal size as to the other investigators' facts that were obtained in the October (equal to 28,0-30,7 $\mathrm{mm})$.

In the January the length of the male's inguinal gland was determined $36-38 \mathrm{~mm}$, what is different from some authors' data in the October in that the present measurement is larger value of the gland than the previous one $(34,4-36,2)$.

Beside this, the asymmetry of the sizes between the left and right lobules of the male's inguinal gland was observed.

\subsection{Histological exploration of the inguinal gland}

According to the great number of received microphotography of the inguinal gland of both sexes on the tissue specimens that are demonstrated below, it's possible to character the inguinal gland as the 
glandular compartment of the entire endocrine system with a certain originality of a composition and a structure.

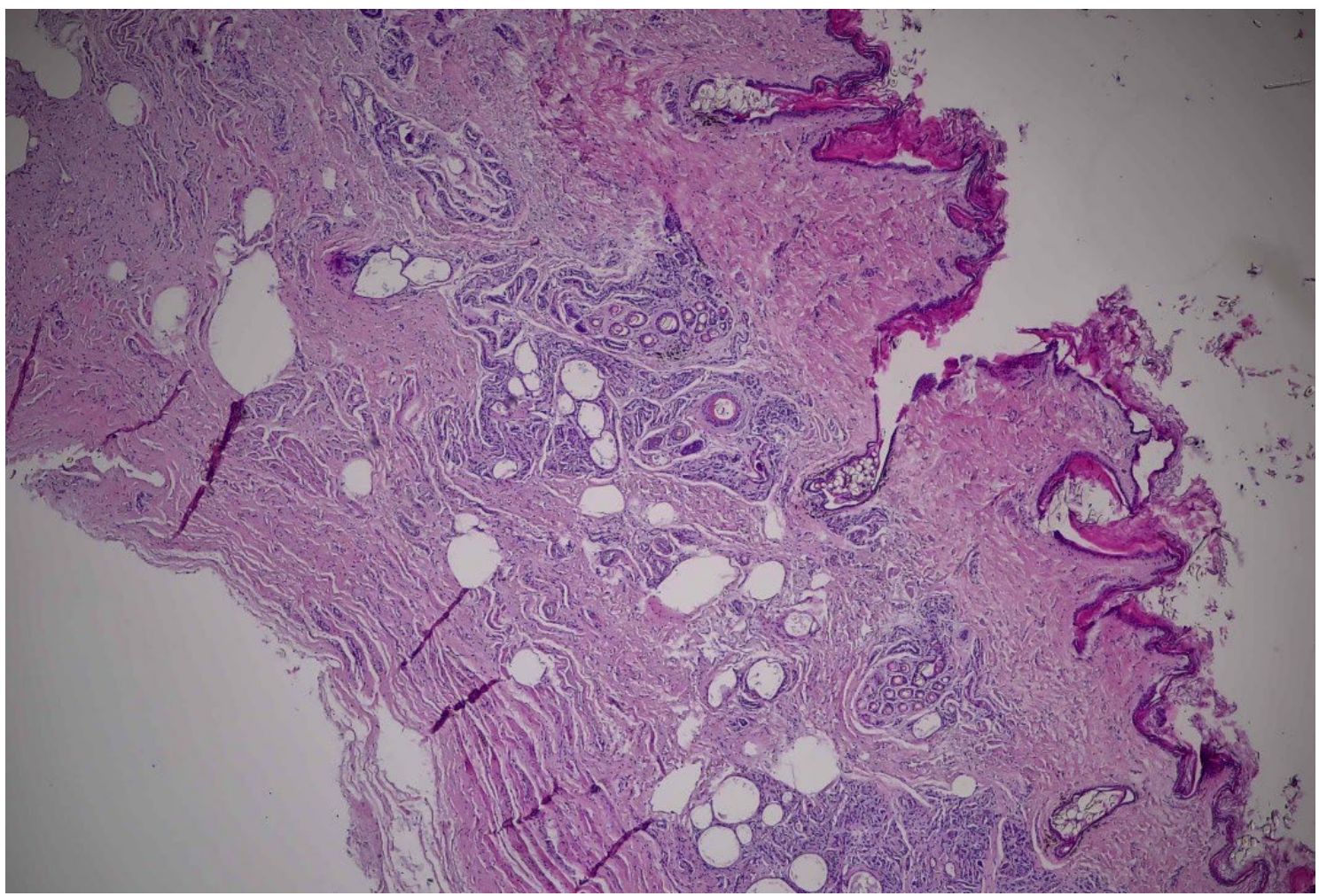

Figure 3. The microphotographs of the male specimen of the inguinal gland. The general view of the inguinal gland's structure and the composition of tissue

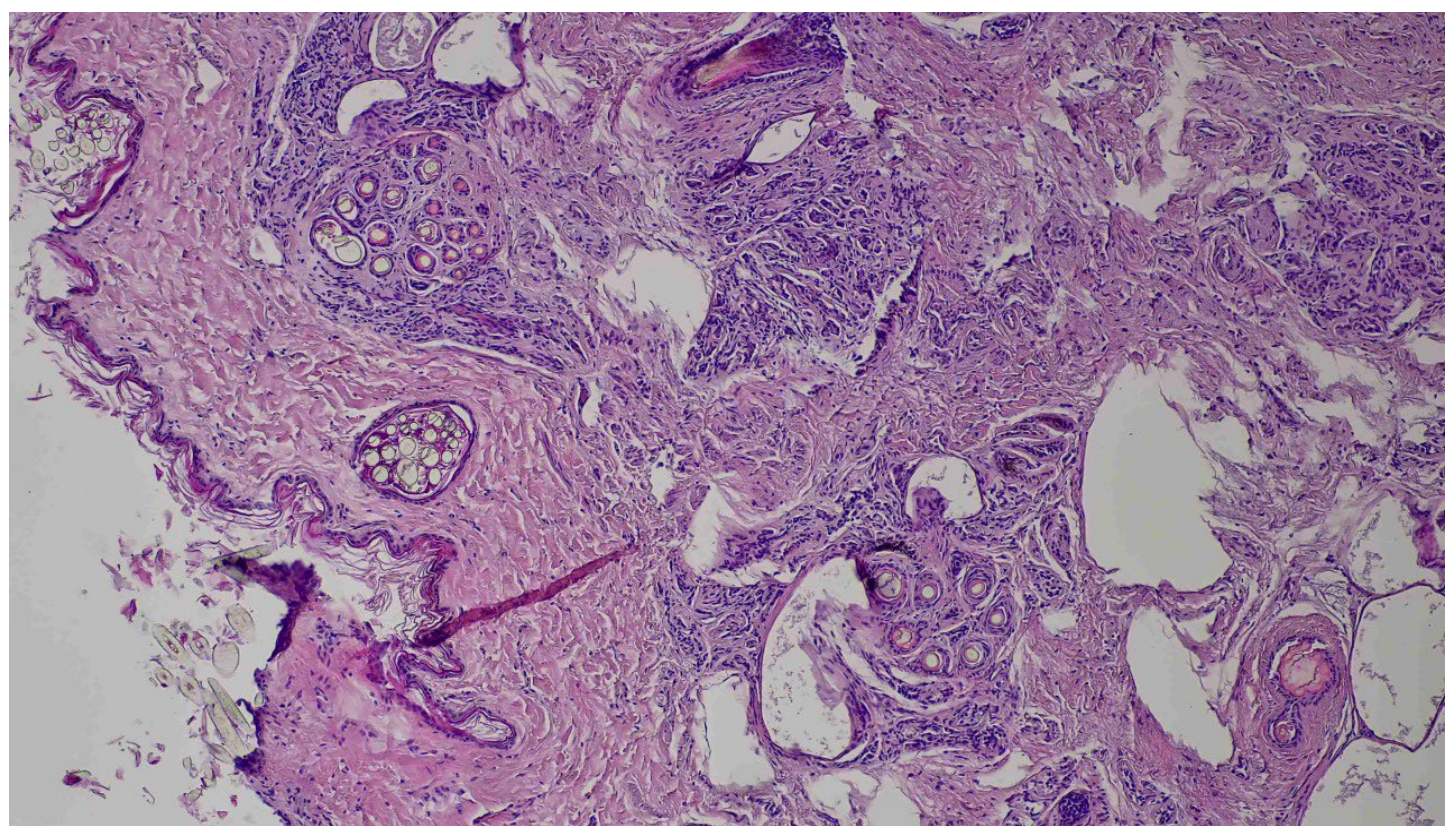

Figure 4. The microphotographs of the male specimen of the inguinal gland. The view of the branched structure of the sebaceous glands, its' excretory ducts, the secret that concentrates in the ducts, the hair sheath and excretes out of the hair follicles 
The inguinal gland is represented by a glandular epithelium and the complex of "thin" skin's appendages that cover the connective-woven strands of tissues and the collagen fibers (the figure 3 ) - the sebaceous glands and the sweat glands. These glands operate as to a certain "scenario" according to appropriate types of secretion, the result of which is the previously described oily secret. On these specimens the sweat glands, that have the apocrine and merocrine types of secretion, are barely observable. However, there are the well-visible structure and the lobules of the still slightly hypertrophied simple alveolar glands - the sebaceous glands, that have holocrine type of glandular secretion. The sweat glands have the branch chain of excretory ducts that is covered the planocellular endothelium. On the figure 4 it's possible to trace the path of a formation and an excretion of the sebum (the secret of the sebaceous glands in the form of the «yellowish drops»): from the ducts of the small secreting compartments of each lobule, gradually merging into a one large duct, to the bag of the hair sheath. Hypothetically, the upper parts of the sebaceous glands are below the layer of the hair roots, and the sweat glands are located in the subcutaneous fiber.

In the tissues, there is a significant amount of newly formed lipid accumulations in the form of white cavities (without a stain) on the samples due to the natural processes of biological destruction and involution of the tissue structure. It's suggested that these cavities had presented the glandulocytes (or the secretory cells) before.

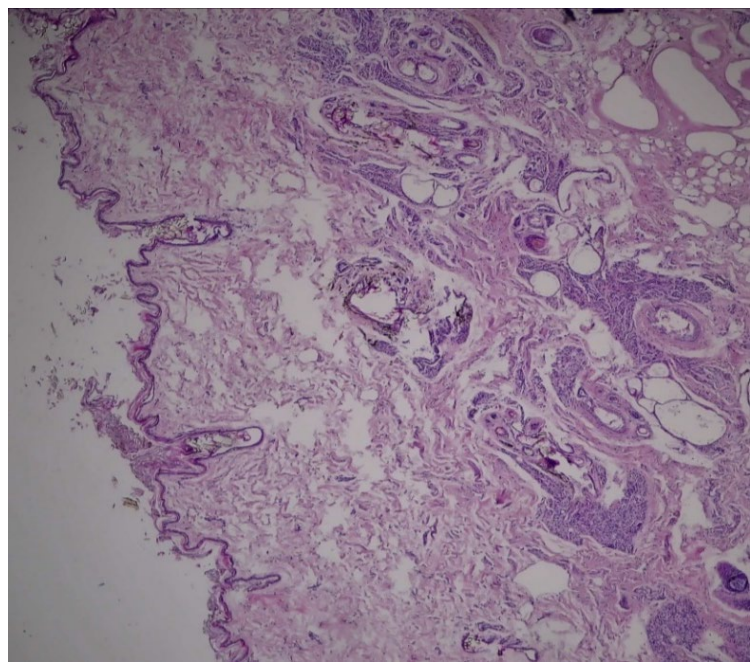

(a)

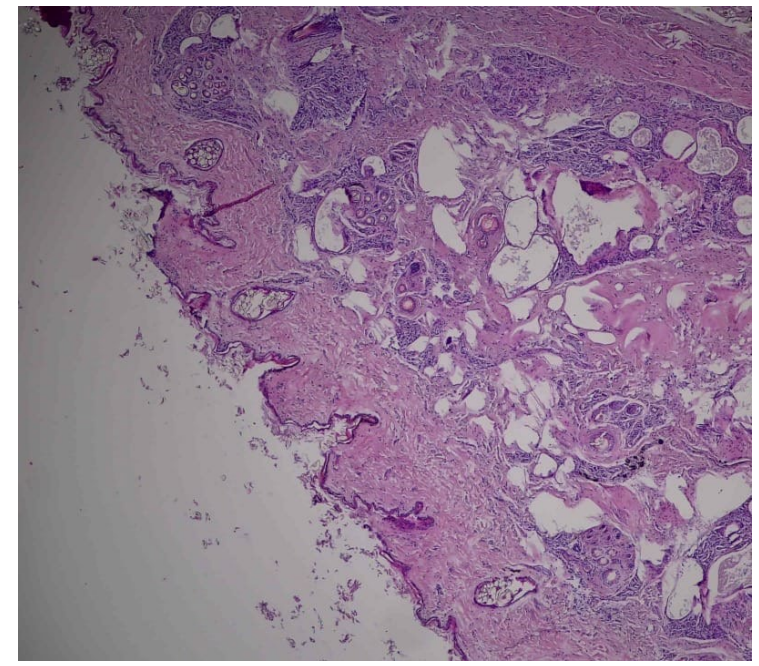

(b)

Figure 5. The microphotographs of the inguinal glands' cross-section: the left photo - the female specimen, the right photo - the male specimen

The general comparison of the obtained results of the histological survey of female and male inguinal glands of Martes zibellina L. is revealed the following (the figure 5). Despite the period under the study, that is characterized by the general state of rest of the inguinal glands (its inactivity can be observed), the male has a greater secretory activity in comparison with the female one. The strong evidence of this statement is a greater amount of secret, that have the male individual on the histological cross-sections, both in the excretory ducts of the sebaceous glands and excreted into the hair follicle. Thus, it may be stated that this time is the transition of the sable organism to a period of an increased 
activity, that is called the "false rutting" (as noted earlier, from February to May), and constitutes such a kind of signal for the preparation to the sexual sphere.

\section{Conclusion}

According to a theoretical review of the literature, the state of the inguinal gland reflects three phenomena in the life of the sable - essentially the inguinal gland as a marking organ (as a marker), an alteration in the state of the sexual sphere and the seasonality of the life cycle. Hence, it may be stated that the plenty of the above listed certain functions of the inguinal gland have a sequence of the changes throughout the whole life of Martes zibellina L.

Morphological and histological explorations show that the inguinal gland of the female is at rest at the end of December, and some secretory activity of the male is observed in the end of January as the preparation to the "false rutting".

The results of the study don't contradict the findings that were obtained earlier by other authors.

It's necessary to make further investigations of the structure and functions of this important organ of sable in different seasons of the year. In the future, it's planned to investigate and to comprehend the biological mission of this glandular organ, its role in the chemocommunication among these fur animals, the nature of cubs' seasonal disease "wet belly" (the intertrigo) and the dependence between the inguinal gland and the generative organs of sables.

\section{References}

Asmus, N. A. (1961). Preduprezhdeniye "podmokaniya" u soboley [The signals of "wet belly" of sables]. Krolikovodstvo i zverovodstvo, 6, 31-32.

Batalov, A. V., \& Klyatis, B. D. (1982). Morfofunktsionalnaya kharakteristika i biologicheskaya rol bryushnoy zhelezy sobolya (Martes zibellina L.) i fialkovoy zhelezy pestsa (Alopex lagopus L.) [The morphofunctional characteristics and the biological role of the abdominal (inguinal) gland of the sable (Martes zibellina L.) and the tail gland of the arctic fox (Alopex lagopus L.)]. In V. E. Sokolov (Eds.), Khimicheskiye signaly zhivotnykh (pp.15-35). Nauka.

Chekalova, T. M., Guteneva T. V., \& Chekalov, A. S. (1992). Funktsiya bryushnoy zhelezy u shchenkov soboley (gipoteza etiologii "podmokaniya") [The function of the abdominal (inguinal) gland of sable cubs (the hypothesis of the etiology of ailment "wet belly"]. Krolikovodstvo i zverovodstvo, $6,24-25$.

Ilina, E. D. (1963). Zverovodstvo [The fur farming]. Izd-vo s.-kh. lit-ry. zhurnalov i plakatov.

Kalantaevskaya, K. A. (1972). Morfologiya i fiziologiya kozhi cheloveka [Morphology and physiology of human skin]. Zdorovye.

Manteyfel, P. A. (1934). Sobol [Sable]. KOIZ.

Matveev, B. S. (1942). Kozha, eye zhelezy i podoshvennyye zhelezistyye organy u sobolya (Martes zibellina L.) [Skin, its glands and plantar glandular organs of sable (Martes zibellina L.)]. Zoologicheskiy zhurnal, 21(5), 207-214.

Monakhov, G. I., \& Leontyev, E. M. (1968). Pakhovaya zheleza i eye znacheniye vo vnutrividovykh svyazyakh u soboley. [The inguinal gland and its significance in the intraspecific relationships of sables]. Okhota, pushnina. dich, 22, 52-59.

Petryaev, P. A. (1941). Biologicheskiye osnovy razvedeniya soboley [Biological bases of sable breeding]. Karakulevodstvo i zverovodstvo, 6, 11-14. 
Pocock, R. I. (1925). The external characters of an American badger (Taxidea taxus) and American mink (Mustela vison). Proc. Zool. Soc. London, 17-25. https://doi.org/10.1111/j.10963642.1925.tb03340.x

Raevskiy, V. V. (1947). Zhizn kondo-sosvinskogo sobolya [The life of the condo-sosvinsky sable]. Tsentr. tip. im. K. Voroshilova.

Rozhnov, V. V. (2011). Oposredovannaya khemokommunikatsiya $v$ sotsialnom povedenii mlekopitayushchikh [The indirect chemical communication in mammalian social behavior]. Tovarishchestvo nauchnykh izdaniy KMK.

Ruchkina, Z. S. (2005). Reproduktivnyy potentsial odnoletnikh soboley $v$ usloviyakh kletochnogo soderzhaniya (baza- «Pushkinskiy») [The reproductive potential of annual sables in conditions of the cage's unkeep (the base of research - Sable farm "Pushkinsky")] [Doctoral dissertation]. The Moscow State Academy of Veterinary Medicine and Biotechnology named after K.I.Skryabin

Slugin, V. S. (2004). Oprelost shchenkov soboley [The intertrigo of sable cubs]. In Slugin V.S. (Eds.), Bolezni plotoyadnykh pushnykh zverey $i$ ikh etiologicheskaya svyaz s patologiyey drugikh zhivotnykh i cheloveka. KOGUP.

Sokolov, V. E. (1973). Semeystvo kunits - Mustelidae. Kozhnyy pokrov mlekopitayushchikh [The family of martens - Mustelidae. Mammalian skin]. Nauka.

Starkov, I. D. (1947). Biologiya i razvedeniye soboley $i$ kunits [Biology and breeding of sables and martens]. Mezhdunarodnaya kniga.

Tamar, G. (1976). Osnovy sensornoy fiziologii [Bases of sensory physiology]. Mir.

Tarasov, P. P. (1960). O biologicheskom znachenii pakhuchikh zhelez u mlekopitayushchikh [About the biological significance of the mammalian odorous glands]. Zoologicheskiy zhurnal, 7, 1062-1068. 